\title{
Halat Bu Maher: the past and present use of quarantine in Bahrain
}

Mohamed Qasim Toorani ${ }^{1}$

Dr Hasan Haji Medical Center, Muharraq, Bahrain (Correspondence to: Mohamed Qasim Toourani: mqt13318@rcsi.com).

Citation: Toorani MQ. Halat Bu Maher: the past and present use of quarantine in Bahrain. East Mediterr Health J. 2020;26(7):764-767 https://doi. org/10.26719/emhj.20.083

Received: 06/04/20; accepted: 11/06/20

Copyright (C) World Health Organization (WHO) 2020. Open Access. Some rights reserved. This work is available under the CC BY-NC-SA 3.o IGO license (https://creativecommons.org/licenses/by-nc-sa/3.o/igo)

In December 2019, the first case of COVID-19 was reported in the Chinese city of Wuhan and within months had resulted in an unprecedented global pandemic. Transmitted through close contact and via droplets, a cornerstone of the global efforts adopted against the virus has been social distancing and various forms of quarantine (1). The word 'quarantine' comes from the Italian word 'quaranta' for '40'. This originated in 1377 when the Rector of the Venetian-controlled city of Ragusa declared a 40-day isolation period for land travellers during a plague epidemic (2). However, the origin of quarantining as a practice to control the spread of disease can be traced much earlier, with examples seen in the Old Testament of the Bible (regarding the separation of people afflicted with leprosy), and 2500 years ago during the time of the Greek physician, Hippocrates (3).

Quarantine has consistently shown to be effective in mitigating the mortality and incidence of pandemic diseases, more recently confirmed with the current COVID-19 pandemic. In particular, the early utilization of quarantine in conjunction with other public health measures have been advocated (4). However, the psychological impact from mass mandatory quarantines worldwide should also be considered. Previous studies of quarantined patients had revealed varying prevalence of stress, depression, irritability and post-traumatic stress disorder. Prominent stressors such as prolonged periods of isolation, disease-related anxieties, loss of normal life routine, insufficient information from public health authorities in addition to socioeconomic factors such as unemployment have been identified (5).

Bahrain is an island nation situated in the Gulf Region consisting of 33 natural islands, the most notable being Bahrain Island which hosts the capital city Manama, and Muharraq Island, which is home to the airport. Bahrain's modern health-care system dates back to the establishment of the Mason Memorial Hospital in 1903 by American missionaries, widely believed to be the first Western hospital in the country and one of the earliest in the Gulf Region (6). The country was a British protectorate until it achieved independence in 1971. In the first half of the 2oth century, the country experienced numerous outbreaks of smallpox, cholera, plague, and typhoid fever - necessitating the arrangement of quarantine facilities by the British (7).

Prior to 1930, a quarantine camp was built on the sea shore close to the suburb of Gudaibiya, located to the southeast of Manama. Due to increasing urbanization and the construction of residential houses close to the quarantine site, the State Medical Officer during the late 1920s declared the site to be unsuitable (8). After lengthy negotiations, the Bahraini government sold the site to the British Royal Air Force (RAF) for 13 ooo Gulf Rupees, which included the foreshore between the camp and the sea. The RAF converted the site into a rest camp, since it was very conveniently situated opposite the flying boat anchorage for commercial and military uses (8).

Shaikh Hamad bin Isa Al Khalifa, son of the ruling Shaikh Isa Bin Ali Al Khalifa, leased to the government a small peninsula on the southern shore of Muharraq island, known as Halat Bu Maher, as a site for the new quarantine camp. Built at the cost of 9000 Gulf Rupees in the Islamic Hijri year of 1348 (1929-1930), and with a rent of 4800 Gulf Rupees per annum, the position was very well suited for its purpose. It could be reached by boats during all tides and is connected to the Muharraq mainland by a narrow isthmus. An artesian well was already present on site and a large amount of stone was available for use to construct new buildings, from the ruins of the $\mathrm{Bu}$ Maher fort (Figure 1) (8). The site was mostly utilized for quarantining new arrivals by sea or air.

The site was previously inhabited by Baluchis who only moved after being compensated with land elsewhere on Muharraq island. After they moved, the site was cleared and new buildings were erected (Figures 2 and 3), consisting of one large stone bungalow for the second class passengers, containing four rooms each with an attached bathroom opening into a veranda, and a long stone building divided into three compartments for deck passengers. Adjacent to the buildings there are latrines for men and women, cook houses and bathrooms (9).

The tower of the old fort was repaired and made accessible. Interestingly, the reason cited in British sources was not because it was in any way needed, but rather it was felt that the conspicuous tower - the only one remaining in a place of considerable historical interest - should not be allowed to fall (9). The Bu Maher fort is currently recognized as a UNESCO World Heritage Site (10).

A rough stone pier has been built reaching into deep water and the whole camp is surrounded by a strong 


\section{Figure 1 Blueprint of the Bu Maher quarantine site (9)}

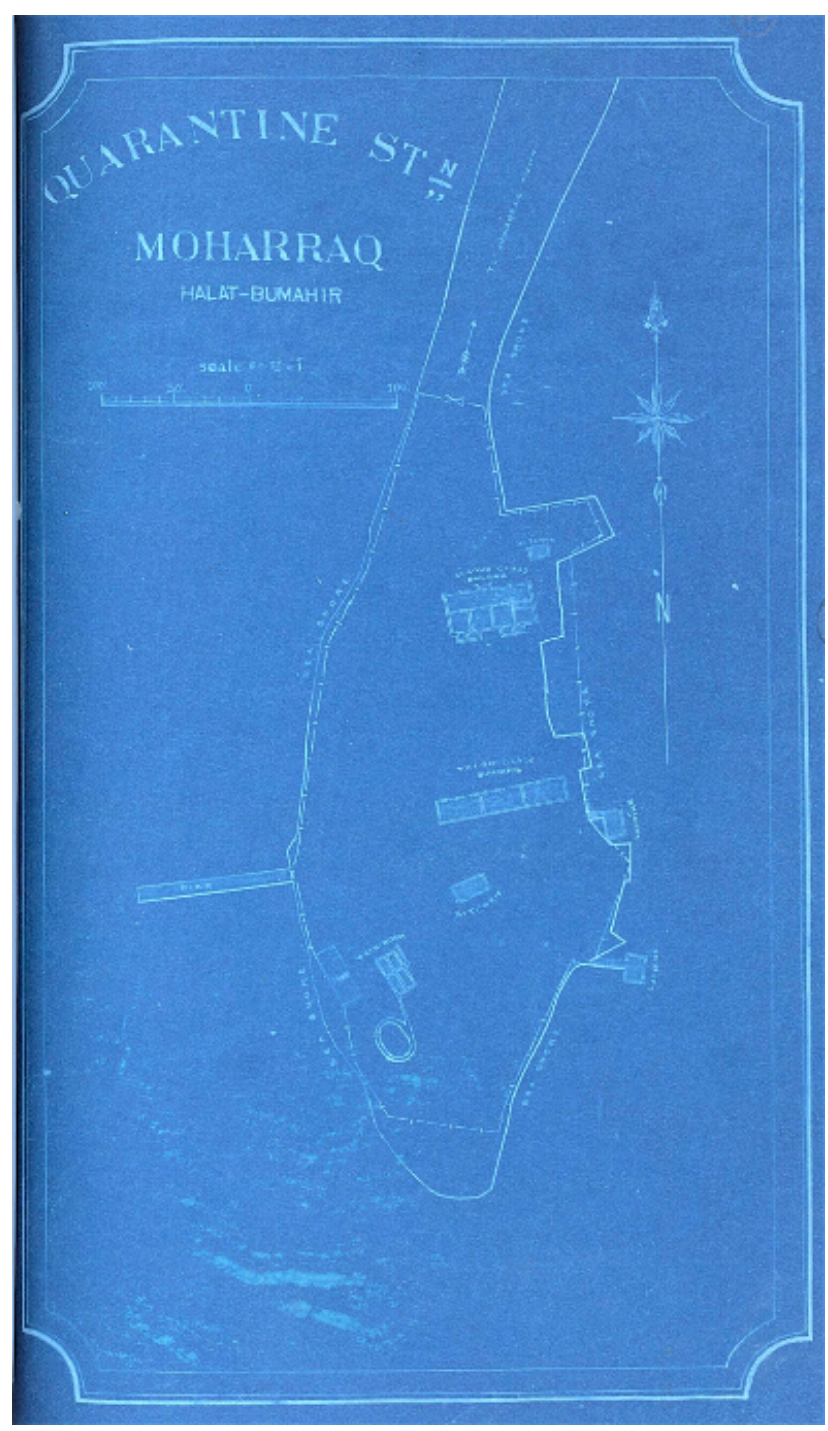

barbed wire fence with a gate at the neck of the narrow causeway, which joins the promontory to the town of Muharraq, and another one on the pier. The work was carried out by the government under the supervision of K.S. Mohamed Khalil of the Muharraq municipality. The new site was considered superior in quality compared to the previous RAF quarantine site, which has since been converted to a resting area (9).

With the advent of effective vaccines to prevent and eradicate diseases such as smallpox and typhoid fever, coupled with massive improvements in public health, the need for quarantine facilities declined over time and the camp was eventually shut down at some point in the latter half of the 2oth century to be reused as a housing project. The last reported outbreak of smallpox in Bahrain was in 1956 and the country was certified smallpox-free in 1978 (11).

Bahrain reported its first confirmed case of COVID-19 on 24 February 2020 in a traveller from the Islamic Republic of Iran (12). Within the weeks that followed, the country implemented a series of precautionary measures including the shutting down of educational institutions, restricting entry to the country to Bahrainis and residents only, and prohibition of public gatherings of more than 5 persons (13). Additionally, Bahrain implemented an extensive contact-tracing programme, utilized locationtracking bracelets to enforce home quarantines, and provided free COVID-19 testing and treatment for all suspected patients irrespective of nationality (14). As of 6 May 2020, Bahrain had conducted more than 160000 tests yielding at least 3900 confirmed cases of COVID-19 (15).

Echoing the lesson of Halat Bu Maher, the Bahraini authorities designated a new man-made island as a quarantine camp for suspected COVID-19 cases in

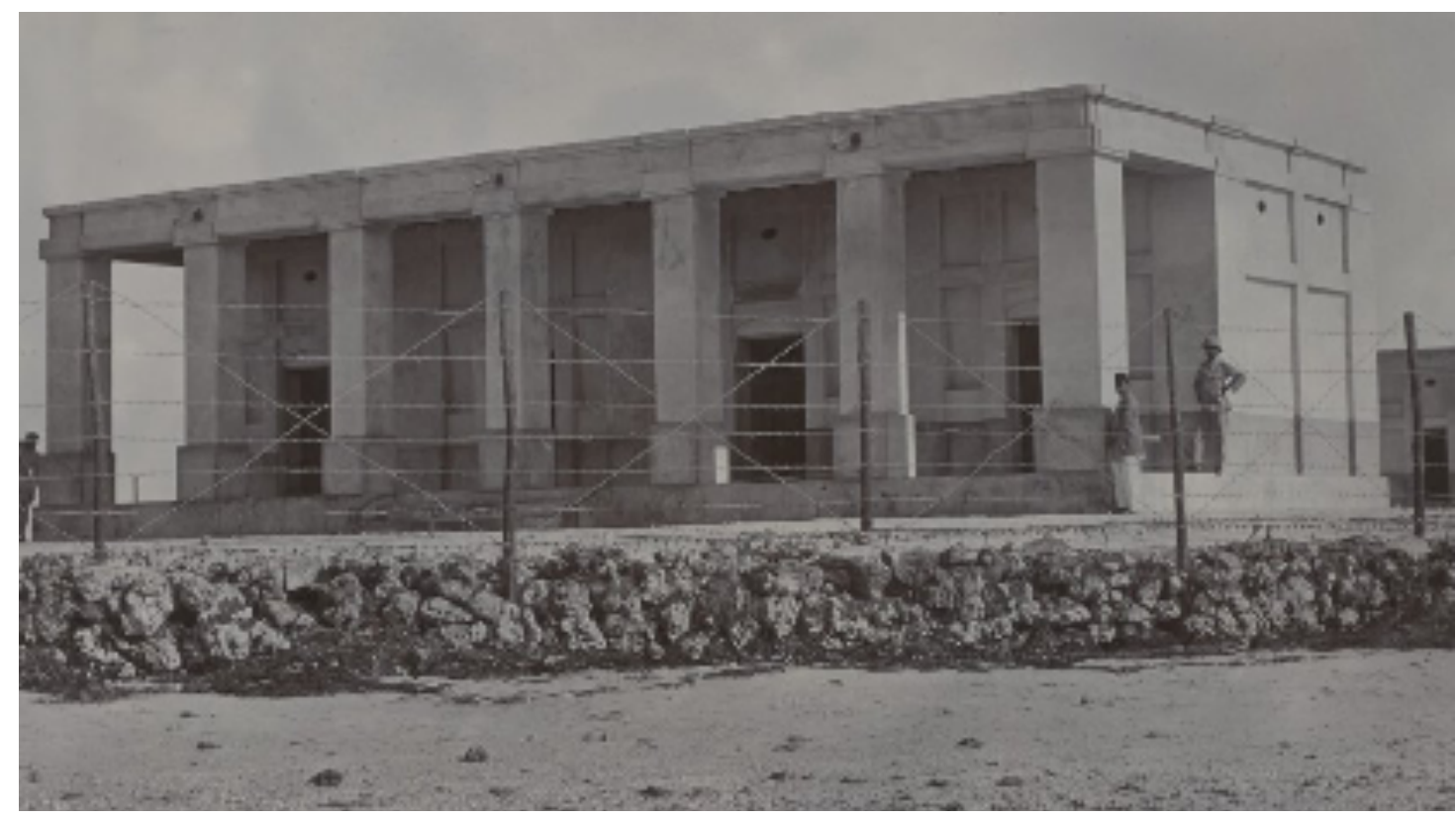

Figure 2 One of the newly constructed buildings in the quarantine site at Bu Maher (8) 


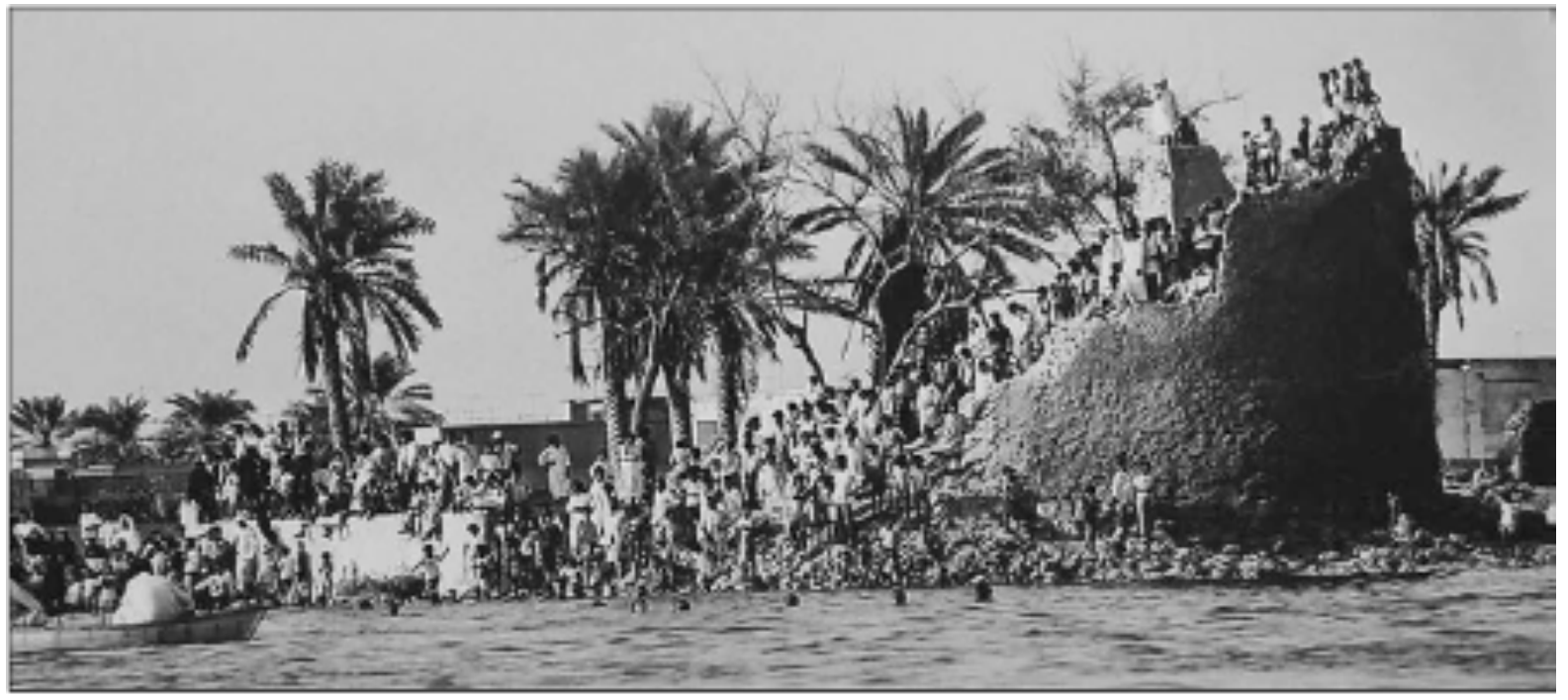

Figure 3 Photograph of Bu Maher Fort, taken from the west, during the 1930s (18)

March 2020. The camp site, built off the coast of Sitra island, has a capacity for 3000 patients and, as with its predecessor, has a narrow isthmus leading to a controlled access point of the camp (16). In May 2020, a 154-bed field intensive care unit was opened adjacent to the quarantine camp, staffing over 300 health-care professionals (17).
In conclusion, as worldwide efforts to develop effective vaccines and medications for COVID-19 continue, social distancing measures, good hand hygiene, and the early utilization of quarantine remain the only effective methods of controlling the COVID-19 pandemic at this stage.

\section{References}

1. Rothan HA, Byrareddy SN. The epidemiology and pathogenesis of coronavirus disease (COVID-19) outbreak. J Autoimmun. 2020;109:102433 doi:10.1016/j.jaut.2020.102433. PMID 32113704

2. Tognotti E. Lessons from the history of quarantine, from plague to influenza. Emerg Infect Dis. 2013 Feb;19(2):254-9. doi: 10.3201/ eid1902.120312.

3. Gensini GF, Yacoub MH, Conti AA The concept of quarantine in history: from plague to SARS. J. Infect. 2004 Nov;49(4):257-61. doi: 10.1016/j.jinf.2004.03.002.

4. Nussbaumer-Streit B, Mayr V, Dobrescu AI, Chapman A, Persad E, Klerings I, et al. Quarantine alone or in combination with other public health measures to control COVID-19: a rapid review. Cochrane Database of Syst Rev. 2020 Apr 8;4(4):CDo13574. doi: 10.1002/14651858.CD013574

5. $\quad$ Brooks SK, Webster RK, Smith LE, Woodland L, Wesseley S, Greenberg N, et al. The psychological impact of quarantine and how to reduce it: rapid review of the evidence. Lancet. 2020;395(10227):912-920.

6. Al-Sayegh F. 1996. American missionaries in the UAE region in the twentieth century. Middle Eastern Studies. 1996;32(1):120-139.

7. File 2908/1907 Pt 2 Bahrain: quarantine arrangements. British Library: India Office Records and Private Papers, IOR/L/ PS/10/124/1, in Qatar Digital Library (https://www.qdl.qa/archive/81055/vdc_100066087729.0x000002, accessed 26 March 2020).

8. 'File 8/9 Bahrain Government Annual Report [67r] (138/298). British Library: India Office Records and Private Papers, IOR/R/15/2/306, in Qatar Digital Library (https://www.qdl.qa/archive/81055/vdc_100025547958.0x00008b, accessed 26 March 2020).

9. Blueprint of the new quarantine site, Bahrain. British Library: India Office Records and Private Papers, IOR/R/15/2/306, f 116, in Qatar Digital Library (https://www.qdl.qa/archive/81055/vdc_100026020540.0x000001, accessed 26 March 2020).

10. United Nations Educational, Scientific, and Cultural Organization (UNESCO). Bu Maher Fort of the Pearling, Testimony of an Island Economy World Heritage site (Bahrain). Paris: UNESCO; 2020 (https://whc.unesco.org/en/documents/168288).

11. Toorani MQ. The Eradication of Smallpox in Bahrain. Journal of Research on History of Medicine. 2016 Feb 1;5(1). (https://iranjournals.nlai.ir/2577/article_634154.html).

12. Abdallah N. Bahrain's first coronavirus case detected. Reuters. 24 February 2020. (https://www.reuters.com/article/us-chinahealth-bahrain/bahrains-first-coronavirus-case-detected-bna-idUSKCN2OIoGP, accessed 10 May 2020).

13. Bahrain News Agency (BNA). Covid-19: Bahrain bans public gatherings exceeding 5 people. BNA 27 March 2020 (https://www. khaleejtimes.com/coronavirus-outbreak/covid-19-bahrain-bans-public-gatherings-exceeding-5-people, accessed 10 May 2020). 
14. Toumi H. Bahrain uses technology to track home quarantine COVID-19 patients. Gulf News. 6 April 2020. (https://gulfnews.com/ world/gulf/bahrain/bahrain-uses-technology-to-track-home-quarantine-covid-19-patients-1.70838518, accessed 10 May 2020).

15. Ministry of Health. COVID-19 Page. (https://www.moh.gov.bh/COVID19/, accessed 6 May 2020).

16. Gopal. Bahrain Coronavirus Quarantine Facility in Sitra. Gulf Daily News. from: https://www.gdnlife.com/Home/ArticleDetail?ArticleId=23058\&category=4, accessed 10 May 2020).

17. Borbon C. Bahrain opens second field hospital for COVID-19 patients in Sitra island. Gulf News, 10 May 2020 (https://gulfnews. com/photos/news/bahrain-opens-second-field-hospital-for-covid-19-patients-in-sitra-island-1.1588659183074, accessed 10 May 2020).

18. Carter R, Morley M, Morse C. Bu Maher Fort, Muharraq. Report on excavations in 2010 for the Ministry of Culture and Information, Bahrain. Oxford: Oxford Brookes University; 2011 (https://www.academia.edu/942118/Bu_Maher_Fort_Muharraq._Report_on_Excavations_in_2010_for_the_Ministry_of_Culture_and_Information_Bahrain). 